\title{
KUBUR-TUMPANG DI KOMPLEKS MAKAM \\ KRT. PANJI CAKRAKUSUMA DI SANGKAPURA \\ (PULAU BAWEAN): SUATU UNSUR BUDAYA ISLAM DI INDONESIA
}

\author{
Oleh: Abdul Choliq Nawawi
}

Kubur-Tumpang adalah suatu makam Islam yang di dalam suatu liang-lahat dikebumikan lebih dari satu jenazah. Penguburan dilakukan secara bersusun tumpang-tindih dan pada susunan paling bawah harus dikebumikan jenazah seorang yang paling ahli dalam penghayatan dan pengamalan terhadap isi Al-Qur'an (Al-Hadits, diriwayatkan oleh Annasaa'ii dan Tirmidzii dengan argumentasi paling benar). Kemungkinan proses ini terjadi karena banyaknya korban yang mati dalam suatu peperangan atau karena banyaknya kematian akibat suatu wabah penyakit yang sangat ganas. Selain itu kubur-tumpang mungkin merupakan pelaksanaan dalam menunaikan nadzar, washiyat maupun amanat. Istilah kubur-tumpang pertama kali muncul di Indonesia sekitar tahun 1970-an yang dilontarkan oleh Prof. Dr. Hamka untuk menerapkan hukum Islam tentang penguburan yang bersumber pada Al-Qur'an dan Al-Hadits sunnah Rasulullah Muhammad SAW sebagai belligrandi (penengah) atas sengketa tanah pemakaman akibat adanya penggusuran tanah-tanah tersebut di Jakarta ketika itu.

Obyek-obyek arkeologi Islam yang sering diungkapkan secara umum dalam konsepsi-konsepsi yang bersifat ilmiah, meliputi penelitian terhadap obyek-obyek kepurbakalaan, seperti: sisa-sisa struktur bangunan kraton-kraton kuna yang masih memiliki karakter Islam, mimbar-mimbar, jirat dan nisan-nisan pada makam Islam dan juga pemugaran sisa-sisa peninggalan masjid-masjid serta kraton-kraton Islam. Sedangkan penelitian terhadap pola penggalian liang-lahat dan jumlah jenazah yang seharusnya dikebumikan di dalamnya sesuai dengan tuntunan agama Islam yang bersumber pada Al-Qur'an 
dan Al-Hadits, kiranya belum pernah diungkapkan secara mantap. Oleh karena itu, dalam kesempatan yang baik ini akan dicoba mengupas sebagaimana lazimnya.

Kubur-tumpang yang dijadikan pokok bahasan dalam tulisan ini dijumpai di dukuh Nagasari, desa Kotakusuma, kecamatan Sangkapura. Pulau Bawean. Pulau Bawean termasuk dalam wilayah administrasi Pemerintah Daerah Tingkat II Kabupaten Gresik, Propinsi Jawa Timur. Pulau tersebut terletak lebih kurang 150 kilometer di sebelah utara Gresik, dengan luas wilayah 19.411,255 kilometer persegi, terdiri atas tanah kering, tanah kehutanan, tanah sawah, tanah pemukiman dan sebagainya. Pulau Bawean terdiri atas dua wilayah kecamatan, yaitu: Kecamatan Sangkapura dan Kecamatan Tambak. Kecamatan Sangkapura terdiri atas 17 (tujuh belas) desa dan Kecamatan Tambak terdiri atas 13 (tiga belas) desa. Berdasarkan statistik yang ada pada tahun 1984, jumlah penduduk Bawean 66.225. jiwa yang semuanya beragama Islam. Bahasa pengantar dalam pergaulan hidup sehari-hari menggunakan bahasa Bawean dialek Kangean dari keluarga bahasa Madura. Desa Diponggo di Kecamatan Tambak, merupakan satu-satunya desa yang menggunakan bahasa Jawa dalam percakapan sehari-hari. (R. Abdurrachman Badruddin, 1985: $3-5$ ).

Suatu hal yang menarik untuk penelaahan epigrafi Islam di daerah ini adalah kuburan KRT. Panji Cakrakusuma di Sangkapura. Pada kubur itu terdapat dua nisan yang memuat nama dua orang tokoh. Nisan kepala (utara), memuat nama seorang tokoh sejarah yang bernama "Kangjeng Rahadian Tumenggung Purbanagara" dan pada nisan kaki (selatan) dicantumkan nama seorang tokoh sejarah dengan sebutan "Kangjeng Rahadian Tumenggung Panji Cakrakusuma Ibnulmarchuum Kangjeng Rahadi Tumenggung Purbanagara". Tulisan itu terdapat pada sisi dalam nisan-nisan tersebut. Selisih waktu kematian mereka 50 (lima puluh) tahun.

Penggunaan istilah "ibnulmarchuum" atau "bin almarchuum" (dari bahasa Arab: ibnun berarti anak kandung) sebagai predikat di belakang nama "Kangjeng Rahadian Tumenggung Panji Cakrakusuma", berarti KRT. Panji Cakrakusuma itu adalah putera kandung KRT. Purbanagara. Bentuk, ukuran dan motif khath Arab yang terdapat pada kedua nisan itu hampir sama. Kedua nisan tersebut 
dibuat dari kayu jati berukir yang terletak di atas satu jirat dan di dalam satu cungkup yang tertutup serta terdapat di dalam cungkup lain yang berukuran lebih besar.

Berdasarkan data tersebut di atas, maka secara faktual diduga bahwa makam tersebut merupakan kubur-tumpang. Terjadinya kubur-tumpang pada makam KRT. Purbanagara dan KRT. Panji Cakrakusuma ini masih perlu dicari sebab-sebabnya serta harus memenuhi 3 persyaratan seperti disebut sebelumnya. Tampaknya hal ini tidak disebabkan karena peperangan maupun wabah penyakit, meng. ingat jangka waktu penguburan kedua jenazah berselisih 50 (lima puluh) tahun. Kemungkinan terdekat dan dapat diterima adalah alasan ketiga, yaitu disebabkan oleh adanya washiyat, amanat, dan mungkin juga dilakukan untuk melunasi pembayaran nadzar (nyaur kaul). Asumsi ini dapat lebih dipastikan apabila didukung oleh data lain yang lebih konkrit, misalnya naskah-naskah peninggalan dari kedua almarhum yang berupa testamen (sarat pernyataan: washiyat/ama. nat) dengan saksi-saksi kerabat terdekat secara turun temurun. Tam. paknya data semacam itu sukar diperoleh dan mungkin juga tidak ada, tetapi meskipun demikian asumsi ini masih dapat diperkuat oleh keterangan yang terdapat dalam Al-Hadits sunnah Rasulullah $\mathrm{Mu}$ hammad SAW sebagai salah satu sumber hukum Islam.

\section{II}

Dalam bagian ini akan dikemukakan rekaman data dari makam KRT Panji Cakrakusuma di dukuh Nagasari, berupa salinan inskripsi pada nisan tersebut di atas. Adapun bunyi khath Arab yang terdapat pada sisi dalam nisan kepala terdiri atas delapan baris (foto: 1), berbahasa dan berhuruf Arab dengan susunan sebagai berikut:

1. Tulisan: 


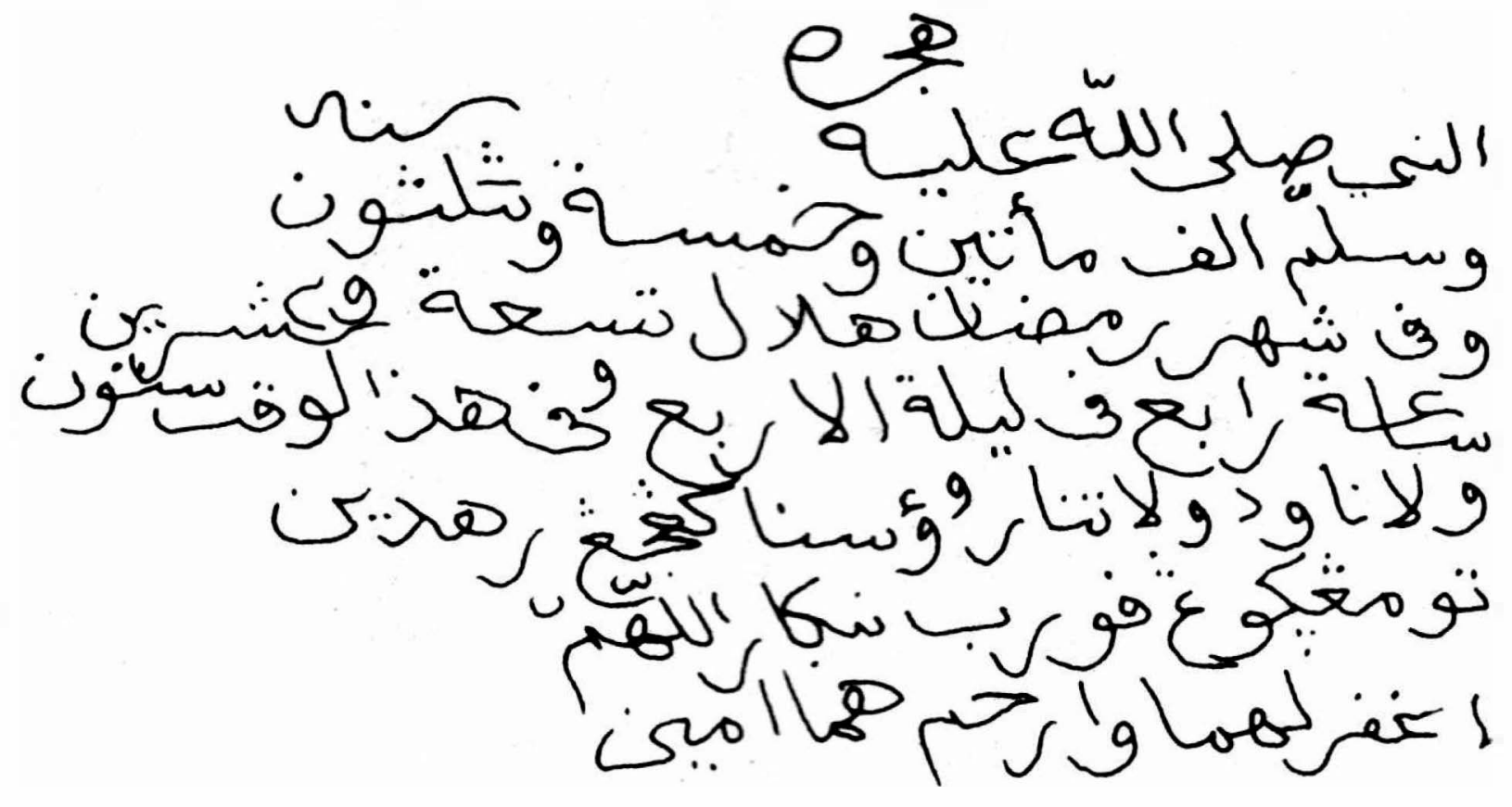

2. Transkripsi:

$\mathrm{Hijrah}$

An-nabiyyu shalaallaahu 'alaihi

wa sallama alfin mi'ataini wa khamsatin wa tsaalitsuuna sanah wa fii syahrin ramadhaana hilaalin tis'ata wa 'isyriina saa'ata raabi'a wa fii haadzalwaqti sittuuna wa lainnaa wa daulaatanaa ru'usinaa Kangjeng Rahadian Tumenggung Purbanagara Allaahummagh-

fir lahuma waarcham humaa aamin.

3. Artinya: "Bahwasanya pada tanggal 29 Romadhon $1235 \mathrm{H}$, malam Rabu, jam 04.00 pada waktu yang ke enam puluh ini, dan sesungguhnya bagi Paduka Kepala Negara kita "Kangjeng Rahadian Tumenggung Purbanagara" (telah wafat), semoga Allah SWT memberikan ampunan atas segala dosa beliau dan memberikan rahmat kepada beliau, kabulkanlah".

Khath Arab pada sisi dalam nisan kaki terdiri atas empat belas baris (foto: 2), berbahasa Melayu dengan susunan sebagai berikut: 
1. Tulisan:

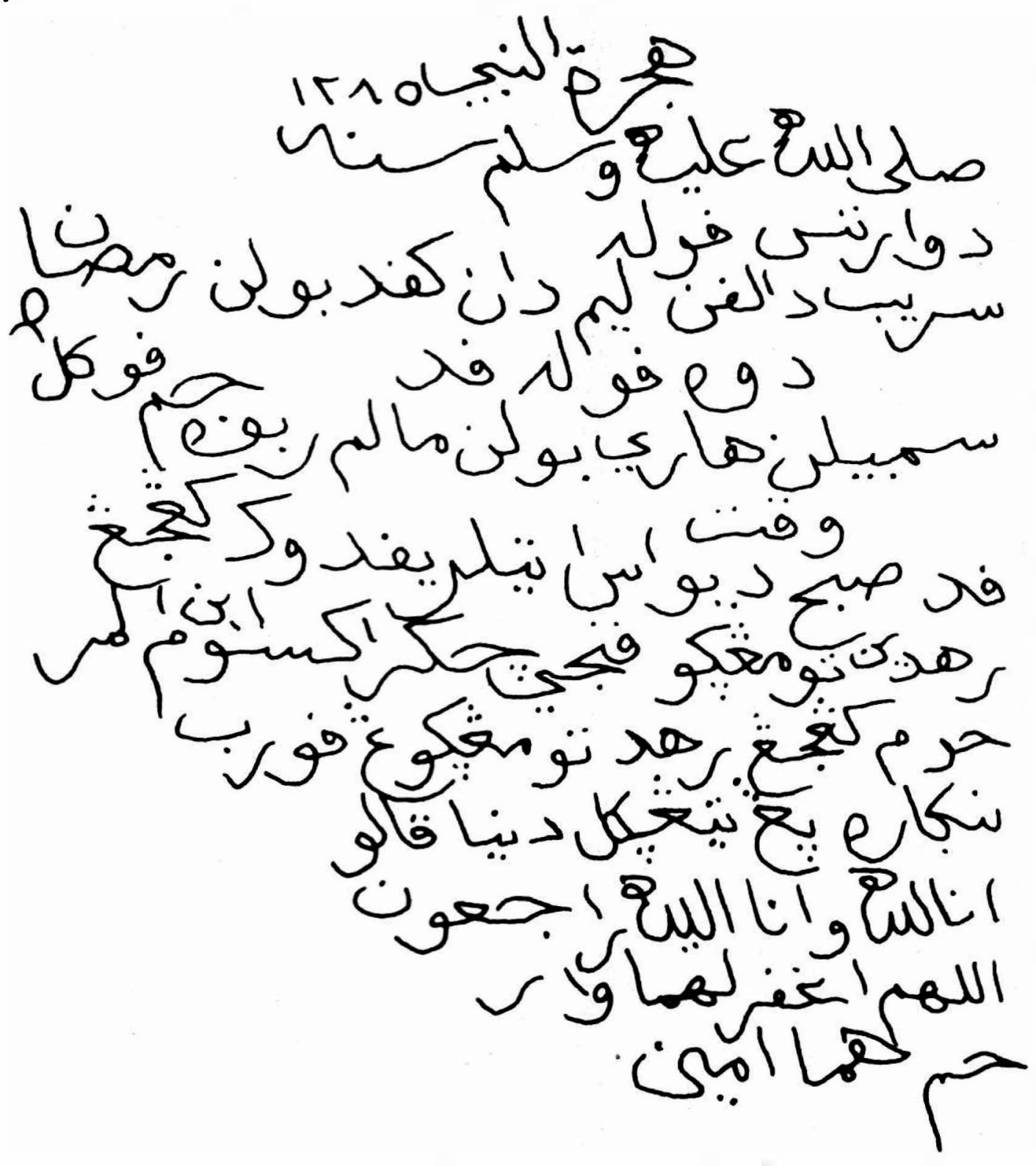

2. Transkripsi:

Hijratu-An-Nabiyyu

Shallaallaahu 'alaihi wa sallama sanah : 1285 dua ratus puluh seribu dalapan lima dan kepada bulan ramadhan dua puluh pada sembilan hari bulan malam Rabu jam pukul 5 waqtu 
pada Shubuh dewasa tilare Paduka Kangjeng

Rahadian Tumenggung Panji Cakrakusuma ibnulmarchuum Kangjeng Rahadi (... ? . . an) Tumenggung Purbanagara nyang tinggal dunia qaaluu innaa lillaahi wa innaa ilaihi raaji'uun Allaahummaghfir lahumaa waarcham humaa aamiin.

3. Artinya: "Tahun 1285 (seribu dua ratus delapan puluh lima) hijriyah, pada bulan Romadhon yang berumur 29 hari pada malam Rabu, jam 05.00 Shubuh, telah wafat Paduka Kangjeng Rahadian Tumenggung Panji Cakrakusuma putera kandung almarhum "Kangjeng Rahadi (. . ? . .) Tumenggung Purbanagara" katakanlah: Sesungguhnya kita semua milik Allah SWT dan sesungguhnya kita semua akan kembali kepada-Nya, Yaa, Allah ampunilah segala dosa kami dan berilah kami sekalian rahmat, kabulkanlah".

Kubur-tumpang bagi ummat Islam di Indonesia memiliki tujuan sosial ekonomis dan tujuan praktis religius. Tujuan sosial ekonomis berupa penghematan tanah untuk pemakaman dan selanjutnya dapat dikembangkan untuk keperluan-keperluan dalam mencapai ketenteraman dan kesejahteraan hidup manusia yang akan datang demi tercapainya kebutuhan akan papan, pangan dan sandang. Sedangkan tujuan praktis religius adalah sebagai pengejawantahan dalam mengikuti jejak-jejak Rasulullah Muhammad SAW yang sebenar-benarnya. Hal itu dapat dikembalikan pada beberapa Al-Hadits sebagai berikut (Asy-Syaukani, t.t.: 84):

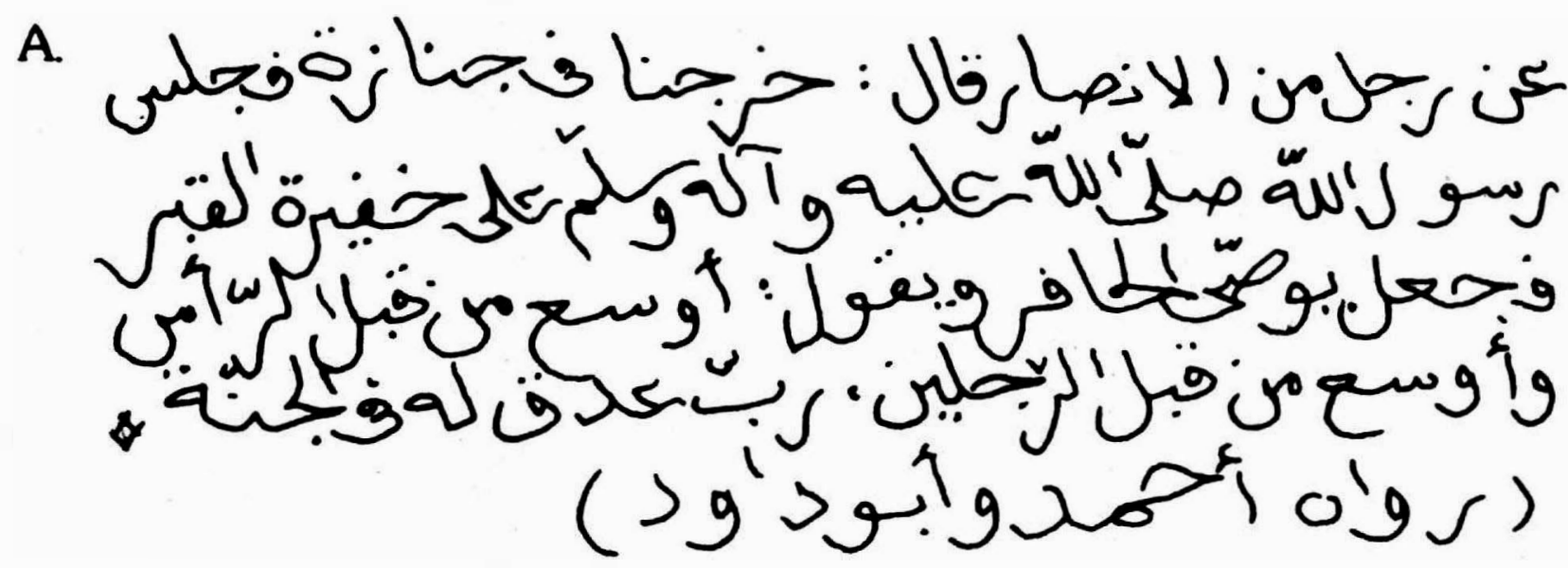




\section{Transkripsi:}

"'An rajulin minal-Anshaari qaala: Kharajnaa fii janaazati fajalasa Rasuulullah shallaallahu 'alaihi wa sallama 'alad chafiiratil qabri. faja'ala yuwashshiilchaafiru wa yaquulu: Uusi' min yablir ra'sı wa uusi' min qablirrijlaini. rubba 'adqin lahu fiil-jannati (Rawaahu Ahmad wa Abuu Daawud).

\section{Artinya:}

Dari seorang laki-laki sahabat Anshar menyatakan, bahwa Nabi Muhammad SAW telah bersabda: "Keluarlah kamu sekalian dari dalam jenazah itu! Seraya Rasulullah SAW duduk dekat lubang tempat penggalian kuburan itu, serta beliau berwashiyat juga kepada penggali kuburan itu. dan bersabda: "Buatlah yang lebar pada sisi-sisi kepala itu, dan buatlah yang lebar juga pada sisi-sisi bagian sebelah menyebelah kaki itu, yang demikian itu seperti terpeliharanya sebatang pohon kurma baginya (bagi si almarhum) di dalam sorga". (Al-Hadits diriwayatkan oleh Ahmad dan Abu Dawud).

B.

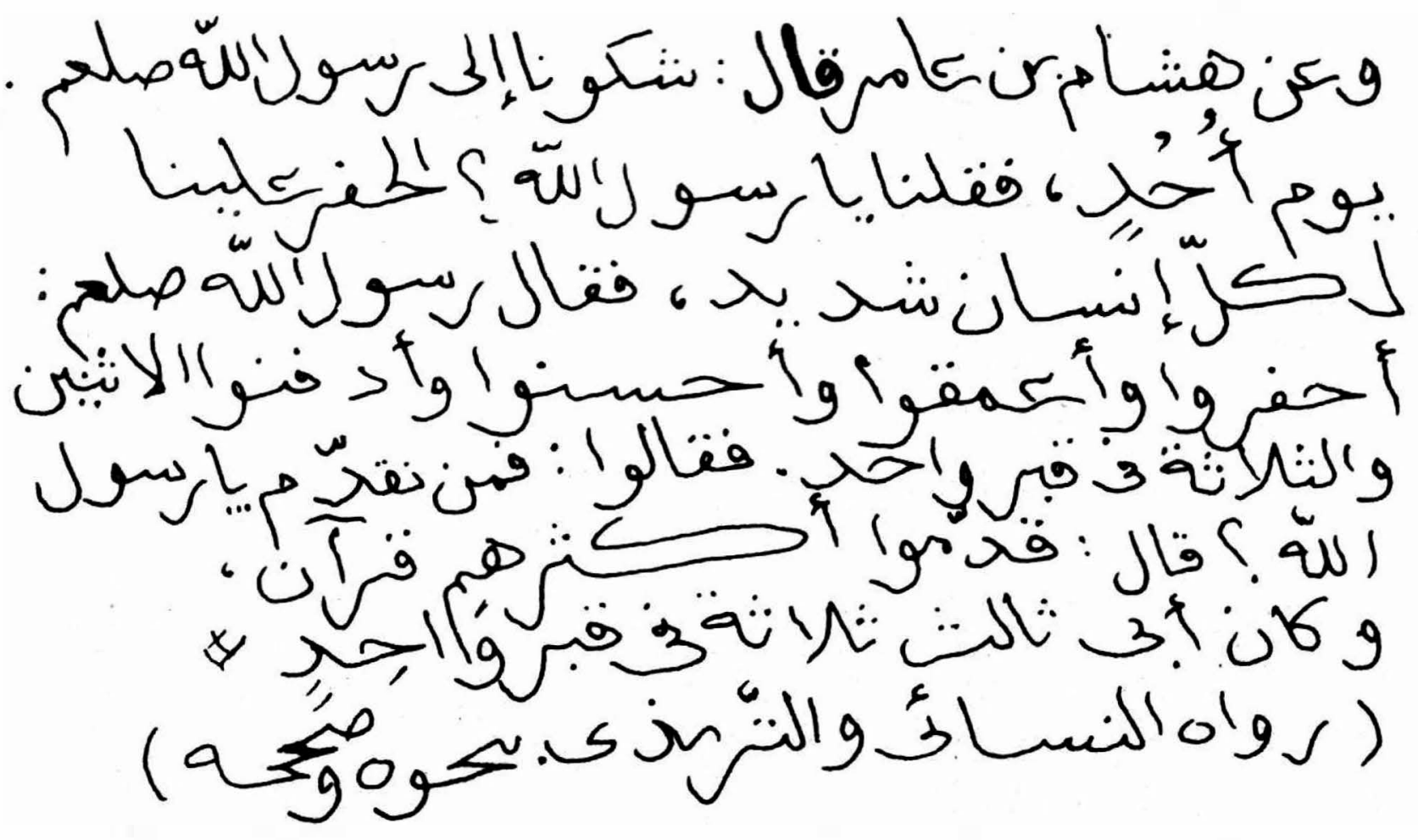




\section{Transkripsi:}

"Wa 'an Hisyaam bin 'Aamir qaala: "Syukuuna ilaa Rasuulillaahi shallaallaahu'alaihi wa sallama yauma Uchudin, faqulnaa, yaa Rasuulullaah, alchafru 'alainaa likulli insaanin syadiidun, faqaala Rasuulullaah shallaallaahu 'alaihi wa aalihi wa sallam: "Achfiruu wa a'miquu wa achsinuu wa adfinuul-itsnaini watstsalaatsata fii qabrin waachidin, faqaaluu: "Faman nuqaddimu yaa Rasuulullaah? Qaala:"Qaddimuu aktsarahum Qur'aanaan, wa kaana Abii Tsaalits tsalaatsatin fii qabrin waachidin".

\section{Artinya:}

Dan dari Hisyam bin 'Amir telah mengatakan, bahwa Rasulullah SAW bersikap tenang ketika terjadi perang Uchud, kemudian kami semua berkata kepada beliau: "Ya, Rasulullah, apakah penggalian liang kubur itu untuk kita semua, juga bagi tiap-tiap insan, Maka Rasulullah SAW bersabda: "Galilah liang kubur itu yang dalam sekali cara menggalinya dan yang amat bagus, serta kemudian kuburkanlah dua jenazah dan atau tiga jenazah dalam satu liang kubur, maka kita semua berkata: "Siapakah yang dikuburkan lebih dulu, yaa, Rasulullah? Setelah itu beliau bersabda: "Dahulukanlah jenazah seseorang yang paling banyak memahami, mengerti, menghayati dan mengamalkan isi Al-Qur'an, dan Abi Tsalits kuburkanlah pada urutan ketiga (di atasnya) dalam satu liang kubur". (Al-Hadits diriwayatkan oleh An-Nasaa'ii dan Tirmidzii dengan argumentasi paling benar). 


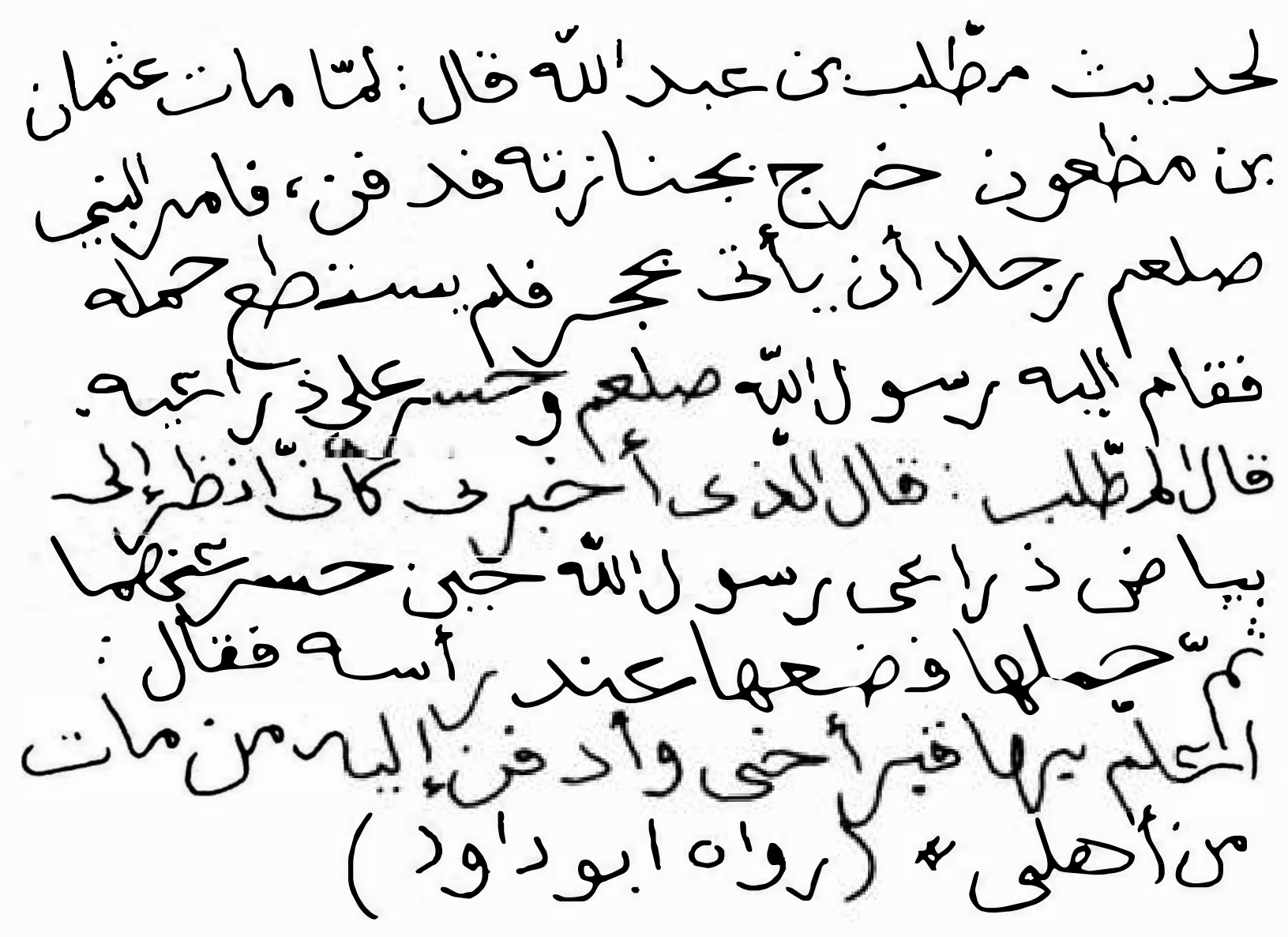

\section{Transkripsi:}

Lichadiitsi Muth-thalib-ibnil-'Abdillaahi qaala: lammaa maata 'Utsmaanubnu Mazh'uunin kharaja bijanaazati fadufina. fa'amara-An-nabiyyu SAW, rajulaan an ya'tii bichajarin falam yastathi' chamlahu faqaama ilaihi Rasuulullaah SAW wa chasara 'alaa dziraa'aihi. Qaalal-Muth-thalibu: Qaalalladzii akhbaranii ka'annii anzhuru ilaa bayaadhi dziraa'aa Rasuulillaahi chiina chasara 'anhumaa tsumma chamlahaa fawa dha'aha'inda ra'sihi faqaala: U'allimu bihaa qabri akhi wa adfinu ilaihi man maata min ahlii (Rawaahu Abuu Dawud).

\section{Artinya:}

Karena hadits Muth-thalib bin 'Abdullah, bahwa ketika 'Utsman bin Mazh'uun wafat, jenazahnya dibawa keluar dan dikubur; lalu Nabi Muhammad SAW memerintahkan kepada seorang laki-laki supaya mengambil batu, maka ia (laki-laki itu) akan mengangkatnya tetapi tidak terangkat lalu Rasulullah SAW mendekatinya dan menyingsingkan kedua lengannya, kata 
Muth-thalib: Memberitakan khabar itu kepadaku bahwa seolaholah aku melihat kedua lengan Rasulullah SAW yang putih waktu disingsingkannya. Kemudian beliau SAW membawa batu dan meletakkannya di arah kepalanya, dengan sabdanya: "Aku memberi tanda kubur saudaraku ini dan aku akan mengubur di situ juga dari ahliku yang meninggal dunia". (Al-Hadits diriwayatkan oleh Abu Dawud, Pimpinan Pusat Muhammadiyah. 1971: 257-8).

\section{III}

Di tanah asal kelahiran agama Islam, tradisi kubur-tumpang ini dapat dijumpai di salah satu bukit dekat kota Mekkah. Letak bukit itu agak miring dan di sebelahnya terdapat lembah yang dalam. Apabila kubur-tumpang di bukit ini diperlukan untuk penguburan jenazah, maka dipilih salah satu makam yang diperkirakan jasadjasad tubuh jenazah yang dalam liang lahat itu telah berubah menjadi tanah. Kemudian makam yang sudah dipilih tadi digaruk dan garukan tanahnya dibuang ke dalam lembah. Sisa-sisa tulang belulang juga ikut terbuang dan tertimbun tumpang-tindih dalam lembah itu. Demikian pengamatan dan penghayatan KHM. Wardan Diponingrat, Penghulu Kraton Yogyakarta, juga Ketua Majlis Tarjih, Pimpinan Pusat Muhammadiyah di Yogyakarta, dalam menyampaikan pengalamannya ketika mengikuti ta'ziyah (pelayatan) di Mekkah, bagi jenazah Jama'ah Haji Indonesia yang meninggal dunia di sana (Pimpinan Pusat Muhammadiyah, 1971: 254).

Secara kebetulan pada beberapa daerah di Indonesia, ketika jaman prasejarah pernah terjadi cara-cara melaksanakan penguburan jenazah tumpang-tindih dalam satu liang lahat, juga lebih dari satu jenazah. Kiranya agak mirip dengan kubur-tumpang di makam KRT. Purbanagara dan KRT. Panji Cakrakusuma ini. Seperti halnya kubur-campuran di pantai Teluk Gilimanuk, Bali, yang pernah digali oleh tim ekskavasi dari Urusan Nirleka dan Kekunaan Prasejarah, Lembaga Peninggalan Purbakala Nasional di Djakarta bersama anggauta tim yang terdiri atas mahasiswa-mahasiswi Jurusan Ilmu Purbakala, Fakultas Sastra dan Kebudayaan, Universitas Gadjah Mada, sekitar bulan September 1964. Di situs kubur-campuran prasejarah ini sejak penggalian tahap awal hingga yang terakhir, sama 
sekali belum pernah ditemukan sepotong menhir yang berdiri tegak di atas tanah sebagai tanda adanya kuburan di dalamnya. Meskipun di atas permukaan tanah situs Gilimanuk sering dan banyak ditemukan sisa-sisa bekal kubur. seperti: manik-manik. pecahan-pecahan kreweng berhias, beberapa fragmen tulang manusia dan sebagainya (R.P. Soejono, 1977: 2; foto: 145-6). Dalam Al-Qur'an Surat Al-Maidah: $27-31$. Allah SWT telah memberikan petunjuk kepada setiap manusia melalui peristiwa pembunuhan atas diri Habil yang pernah dilakukan oleh Qabil. Kedua-duanya adalah putera Nabi Adam AS. Setelah Habil mati terbunuh, maka Qabil kebingungan karena tidak mengerti cara-cara menguburkan jenazah si korban. Kemudian Allah menyuruh seekor burung gagak untuk mengkaiskais bumi, memperlihatkan kepada Qabil bagaimana seharusnya ia menguburkan jenazah saudaranya itu. Cara yang demikian itupun segera ditiru oleh Qabbil. Lalu terdapatlah kuburan manusia yang pertama dan tertua di dunia. (Saadan Rahmany, 1978: 17).

Berdasarkan uraian tentang isi tiga Al-Hadits dan data bandingan di atas, maka kubur-tumpang di Bawean merupakan hal yang disunnahkan (dianjurkan) pelaksanaan 'amaliahnya bagi setiap muslim maupun muslimah pada setiap waktu, karena sesuai dengan anjuran yang tersirat dalam kutipan Al-Hadits yang ketiga. Hal ini membuktikan, bahwa di Bawean sunnah Rasulullah SAW telah dikenal dan dilaksanakan sejak 1825 sampai $1875 \mathrm{M}$, seperti termaktub dalam penemuan epigrafi Islam di daerah ini. Dengan dijalankannya syari'at Islam secara baik dan benar di daerah ini, sejak beberapa abad yang lampau, bukan berarti bahwa sisa-sisa warisan budaya Indonesia itu harus dimusnahkan. Sebab kubur-tumpang yang terdapat di makam KRT Panji Cakrakusuma dan KRT Purbanagara, kecamatan Sangkapura yang merupakan salah satu unsur budaya Islam di Indonesia adalah tidak bertentangan dengan ajaran Islam.

Diharapkan akan dapat diungkapkan lebih luas lagi tentang kubur-tumpang yang mungkin terdapat juga di daerah-daerah lain di Indonesia. Hal ini secara tidak langsung juga merupakan usaha pengembangan penelitian epigrafi Islam. 


\section{KEPUSTAKAAN:}

Ali, A. Mukti. 1970 An Introduction To The Government Of Acheh's Sultanate", Yayasan "NIDA" Yogyakarta.

Badruddin. Abdurrachman, R. 1985. "Sekilas Lintas Pulau Bawean", Yayasan Pendidikan Islam Umar Mas'us, Bawean. Kabupaten Dati II Gresik.

Goris, R. 1929. "Een merkwaardige vondst op den Tengger, TBG., jilid LXIX.

Lekkerkerker, C. 1935. "Sapoedi en Bawean overbevolking En Ontvolking", Kolonial Tijdschrift.

Muhammad-Asy-Syaukani. "Nailul Authaar Syarah Muntaqaaal Akhbaar", t t.

Pimpinan Pusat Muhammadiyah. 1971. "liimpunan Putusan Majlis Tardjih Muhammadiyah", Cetakan - II.

Rahmany, Saadan. 1978. "Seruan llahi", Yayasan "Da'wah", Jakarta.

Soejono, R.P. 1977. "Sarkofagus Bali Dan Nekropolis Gilimanuk", Seri Penerbitan Bergambar. Pictorial number 1, Jakarta, 1977.

Wirjosoeparto, Soetjipto. 1957. "Sedjarah Kebudayaan India”. Djakarta. 


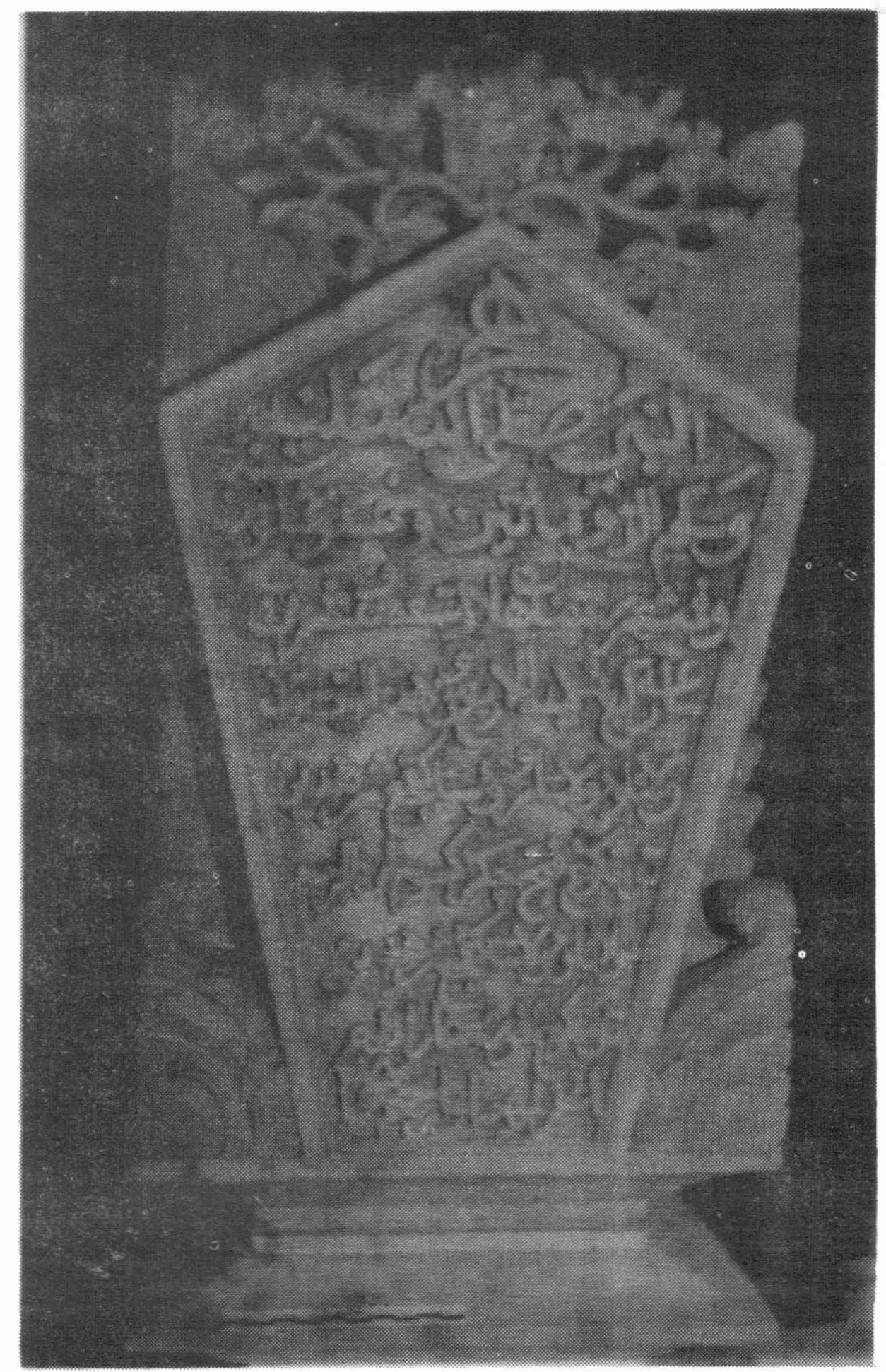

Gambar No. 1

Nisan Kepala. sisi bagian dalam. menyebutkan nama "KRT. Purbanegara" Terletak di situs Nagasari. Kecamatan Sangkapura. Pulau Bawean. 


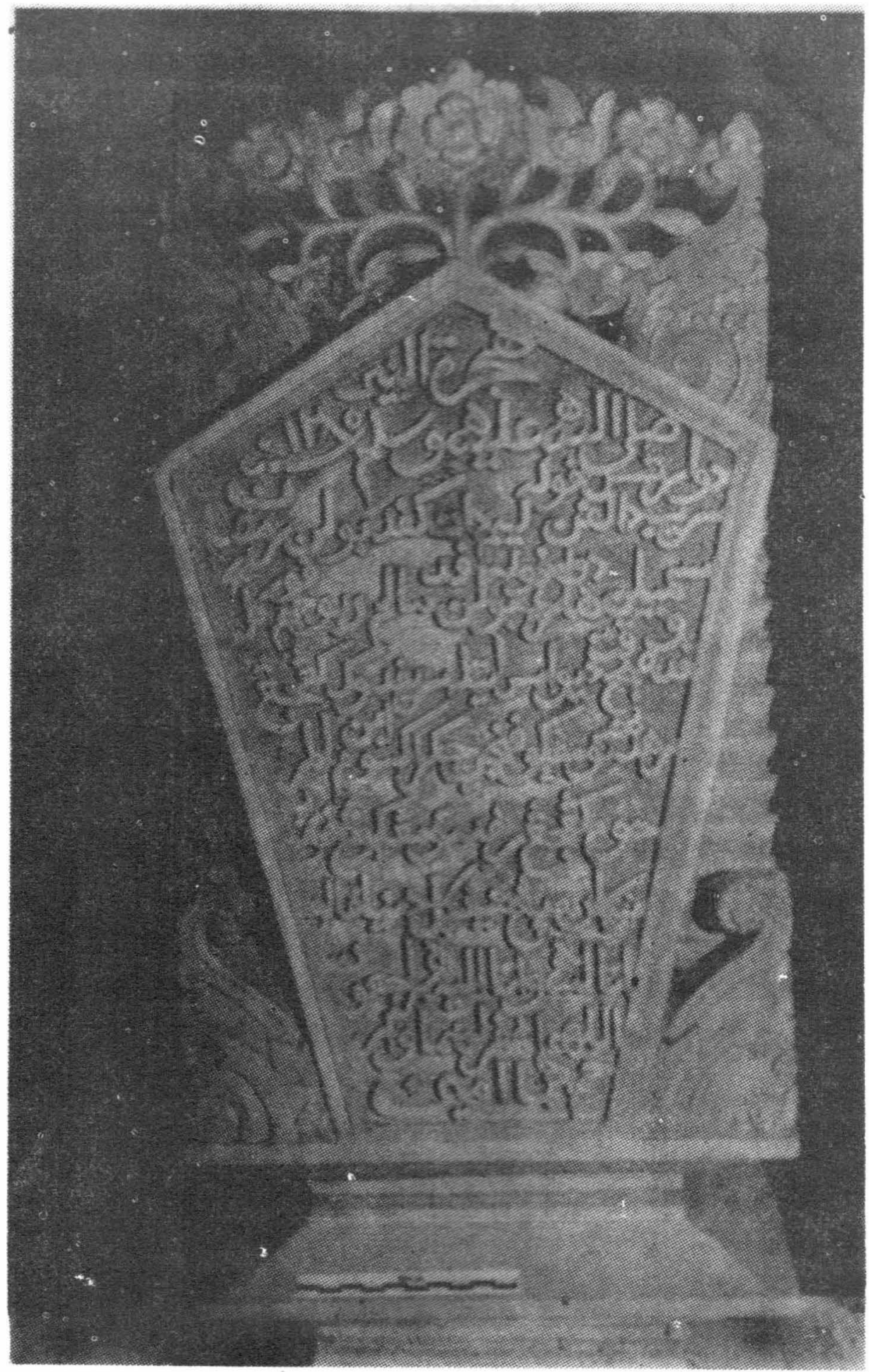

Foto No. 2

-Nisan Kaki, sisi bagian dalam, menyebutkan nama "KRT. Panji Cakrakusuma". Terletak di situs Nagasari, Kecamatan Sangkapura, Pulau Bawean. 